\title{
THE EDUCATIONAL ENVIRONMENT FOR IMPROVING STUDENTS' SELF-STUDY: BEST EUROPEAN PRACTICES
}

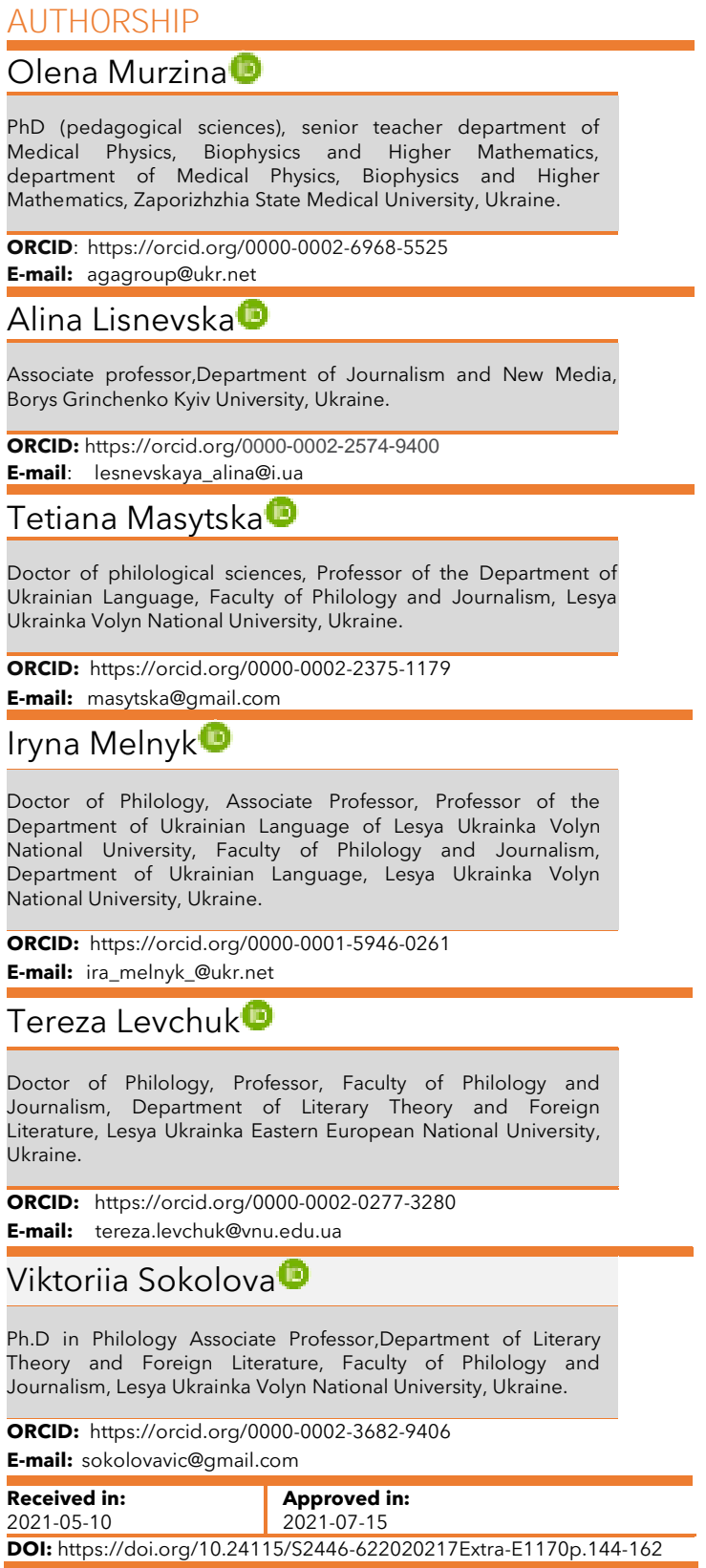

\section{INTRODUCTION}

One of the key areas of scientific discussion in today's educational community is the discussion of reforming the higher education system in European countries. However, in our opinion, the actual topic of such discussions is not just the problems of modernization of higher education, but also rather the search for new principles of such modernization. It is quite obvious that at this time the matter is about the formation of an absolutely new paradigm of education. The universal thesis is that the main task of higher education is to form a creative person of an expert capable of self-development, selfeducation, innovative activity, competitive, initiative, creative thinking, The main goal of the program is to provide the students with the knowledge and skills they need for a continuous professional growth and professional and social mobility. This task requires, first of all, changes in the very conceptual framework of teaching, since the formation of such a person is hardly possible only through mechanical transfer of knowledge in the ready-made form from the teacher to the student.

In the new educational paradigm, the student must become an active subject who can competently formulate a problem, analyze possible ways to solve it, find the optimal result and prove its correctness. Therefore, in essence, it is about changing the paradigm of learning into a paradigm of education. From this perspective, students' self-study does not just become an important form of the educational process - it becomes its basis.

\section{LITERATURE REVIEW}

In foreign literature, self-study is often interpreted as "independent learning" and "selfregulated learning". Note that students who self-study often participate more actively in learning tasks, such as reading online learning materials, completing class assignments, planning, and assessing learning milestones. Jossberger et al. (2010) noted that Self-Directed Learning (SDL) refers to the psychological processes of students who direct themselves to gain knowledge and understanding of how to solve problems. According to Lee, Teo (2010), high-level self-management is important in SDL, and students need to use different strategies to solve a variety of problems. According to Gilbert, Driscoll (2002), similar to self-directed learning, SDL also emphasizes goal setting and decision-making, which are important for students' collaborative learning. The difference between SDL and self-regulated learning lies in the necessary skills. Scientists Jossberger et al. (2010) believe that SDL constructs are at the macro level, while self-regulated learning constructs are at the micro level. 
Noeles (1998) try the topologization of foreign scientists' views on the problem of selfsufficiency in the study. Some scientists, such as Broad, (2006), Poon (2013), Sloman (2007) understand self-sufficiency as "independence" of those who study. They are given educational materials that they can use at their own discretion. This means that students receive a "package of materials" and use them without the physical presence of the instructor. This includes the widespread practice of dictating homework and the more modern form of computer-assisted instruction.

For Donnelly (2010), Mitchell, Honore (2007), self-study means "active awareness of the student's own responsibility. Unlike the first point of view, the student is not seen as a passive entity who understands everything, follows the curriculum by ear, and accepts everything that is offered, but as an active participant in the process. He is able to independently or together with others to make decisions related to his education. When studying the material, he or she not only takes it, but also is able to give it back. This is not about the independence of the one who receives knowledge, but about the independence of the active participant in the process of acquiring knowledge. The knowledge thus acquired is partly a product of the student himself.

For the third group of scientists including Yen, Lee (2011), Singh (2010), self-sufficiency means "ability to learn". In this case, the notion of "self-efficacy" does not describe a characteristic of the learning process, but rather the power of students. "Self-efficiency" can be described as someone who learns, who is "capable of learning."

Thus, as Andryenko (2018), Owston et al. (2008), foreign pedagogy, examining the specificity of the organization of self-study of students, pays special attention to the social aspect of its implementation, associated with the development of the necessary personal qualities: independence, autonomy, trustworthiness, decision-making. For today's European education self-sufficiency in this case is one of the most important criteria for the competitiveness of a person, his/her social and cultural adaptation and development. That is why in preparing tasks for self-study teachers' focus on integrative approach, interdisciplinary and interdisciplinary links in order to expand students' abilities to use information from different sources and sign systems.

Nowadays Ukrainian scientific pedagogical literature gives different definitions of the notion of "students' self-study": through "teaching method", through "systems of receptions", through the description of ways to control students' actions, through the level of self-study when solving educational tasks, etc. The methodological literature presents and reports on various types of self-study. For example, self-study is distinguished by self-study during the main classroom sessions (lectures, seminars), self-study under the control of the teacher in the form of planned consultations, creative contacts, workshops and readings, and selfguided learning in the form of homework of educational and creative nature (PETUKHOVA, HLOTOVA, 2008).

\section{THE MAIN AIMS OF THE RESEARCH}

Objective of the research - identification, substantiation and experimental testing of the effectiveness of improving students' self-study based on the use of the Moodle electronic learning environment.

In accordance with the goal set, the following tasks were formulated: to disclose the essence and meaning of the concept "self-study of students"; to identify indicators of the level of formation of students in domestic institutions of higher education of knowledge, skills and skills of self-study work; experimental testing of pedagogical conditions for the organization of students' self-study in VITE KNUTE, VNAU and DonNU in the Moodle environment with the aim of its improvement; determine the effectiveness of the suggested model for improving self-study of students of higher education institutions in conditions of using the Moodle learning environment. 


\section{RESEARCH METHODS AND MATERIALS}

The methodological basis of the research was the approaches, positions of educational psychology and pedagogy about pedagogical activity. The development of experimental structural model of using the Moodle learning environment to improve students' self-study was carried out within the framework of constructive and creative paradigms in pedagogy intensification of the educational process, as well as activity-based (G. S. Batischev, J.S. Vigotsky), competence (A.B. Khutorsky, V.D. Shadrikov, V.I. Baidenko), systemic (A. Aver'yanov, V.I. Zagvyazinski, V.I. Zagvyazinski, V.V. Baidenko). Zagvyazinsky, V.S. II'yon, V.A. Kan-Kalik, V.A. Lectorsky, others), problem-based and personal and organizational approaches (E. II'yonko, A.B. Margulis).

In the process of the pedagogical experiment the complex of research methods was used, which complement each other: theoretical (analysis of philosophical, pedagogical, psychological and scientific and methodological literature; analysis of foreign experience of improvement of self-study of students; modeling); empirical (triple-factorial observation; social methods - questionnaires, interviews, observations; diagnostic methods - tests; methods of factor and correlation analysis); statistical - statistical and mathematical processing of the data obtained, qualitative and quantitative analysis of the results.

The sample of empirical research included 373 1st-4th year students of the Vinnitsa Institute of Trade and Economics of Kyiv National University of Trade and Economics (VITE KNUTE), Vinnitsa National Agricultural University (VNAU), and Donetsk National University named after Vasil Stus (DonNU). StatSoft STATISTICA 6.1 and EQS 6.1 packages were used for data processing.

To diagnose the effectiveness of improving students' self-study under the conditions of using the Moodle electronic learning environment we used: 1) questionnaire; 2) P. Honey, A. Mumford test (HONEY, MUMFORD, 1986); 3) F. Guay Academic Motivation Scale (SIMS) modified by T.O. Gordeeva and E.N. Osin (GORDEEVA, OSIN, 2011); 4) Intra- and Outward Motivational Orientation Inventory by T. Amabile, modified in relation to the peculiarities of students' self-study (AMABILE, 1994); 5) the method "Subjective Choice Identity" (NEUROVA, $2016)$; 6) the EOS test "Motivation of Success and Fear of Failure" (REAN, 2002).

An empirical study of the effectiveness of improving the independent learning of students of Vite Knute, Vnau, DonNU in the application of the Moodle environment was conducted in four stages:

1. Conducting a survey among students of higher education in order to determine the current state of their independent learning: to clarify the main difficulties of its organization by both students and teachers, their attitude to the use of learning environment Moodle, their understanding of its essence, degree use of information and communication technologies.

2. Identifying the formation of the motivational component of students' readiness for independent learning.

3. Experimental verification of the created and substantiated pedagogical conditions of the organization of independent training of students of institutions of higher education in the Moodle environment.

4. Determining the effectiveness of the proposed model for improving students' independent learning, as well as the level of satisfaction with them.

To diagnose home learning motives we used the Scale of Academic Motivation (SIMS) by F. Guay, modified by T.O. Gordeeva and E.N. Osin (GORDEEVA, OSIN, 2011).

The hardnesses were grouped into four subscales: 1) the scale of intrinsic cognitive motives, which characterizes interest, joy and satisfaction in the process of cognition; 2) the scale of intrinsic motives of attainment describes the feeling of personal significance and awareness of the self-activity performed; 3 ) external motivation scale (external), which describes the learning process that is stimulated by the need to fulfill the undertaken duties and feelings of guilt; 4) amotivation as lack of interest and awareness of self-determined activity. 
The Intrinsic / Extrinsic Motivation Inventory by T. Amabile (AMABILE, HILL, HENNESSEY, TIGHE, 1994) was used to diagnose intrinsic / extrinsic motivation. The inventory consists of two main scales that are focused on diagnostics of intrinsic motivation of achievement as giving benefits to new, exciting and important tasks and extrinsic motivation of achievement as giving benefits to external benefits and social recognition.

To diagnose the peculiarities of the choice of the faculty (and accordingly the study profile) the method "Subjective choice quality" (LEONTEV, MANDRYKOVA, FAM, 2007) was used. This technique allows us to obtain data about the experience of a concrete choice situation: it is being thoughtful, self-confident, having confidence in one's choice, having a positive or negative emotionality of choice.

The use of psychological and pedagogical testing of students (P. Honey and A. Mumford test) allows you to identify their personal learning style in the process of self-study; to correct the content of the electronic learning environment (adaptive technology) taking into account the home style behavior of students, identified as a result of the test.

Using the results of the test by P. Honey and A. Mumford, you can create an indicative picture of individual characteristics of the student, which relate to the analysis and transformation of information and most often manifested during the negotiation of educational tasks. The test contains 80 items that students may or may not agree with, as well as a key for calculating the scores. A score is awarded for each test item. The submitted key determines the learning style most appropriate for the person being tested. The authors distinguished 4 learning styles: pragmatist, thinker, theorist, and activist.

\section{RESULTS OF THE STUDY}

It should be noted that the historical context of the development of students' self-study in Western universities is associated with the name of $W$. von Humboldt, who reformed education and emphasized the idea of forming a truly creative person. "The Humboldt University was the name given to this new model of higher education, which differs from previous models in two fundamental principles: academic freedom and the continuity of teaching and research. The current system of higher education in Western Europe continues the tradition of the Humboldt University by actively developing students' project-based activities that combine scientific research with practical solutions to a specific problem or task (LEBEDEVA, 2016).

Taking into account the above mentioned, it is necessary to conduct a review of the practices of improving the self-study of students in the leading European countries. In Great Britain, for example, self-study is called individual. This is about the orientation of the British educational system towards students' self-directed activity (from the standpoint of their self-directed planning and organization of a self-directed course). The self-directed management of their activities and control of the process of their implementation) can be evidenced by the official recognition in the UK HEls of such type of educational workload of the teacher, as an individual work with students. This kind of activity is a consultancy on the main issues on the problems proposed for study and implements in practice the principle of individuation of training.

Practically all students in Great Britain starting from the second half of the term of study switch to individual plans, which are put together with the teacher and take into account the individual pace of learning, the scope and complexity of the educational material, the form of exercising control and self-monitoring. The ratio of required and optional disciplines, as well as the minimum volume, minimum and maximum time of implementation, remain strictly regulated and meet the program requirements of a higher education institution. Independent work at UK HEls is allocated up to $60-70 \%$ of the total teaching time. A special role is assigned to the students' consultancy as a special type of individual assistance and a way of managing independent work, as a form of intensive, productive cooperation between the instructor and the student, which influences the motivational sphere and is aimed at spurring students to further cognitive activity and stimulating their creative individuality (BROAD, 2006). 
Nowadays in Great Britain, more and more information technologies are used for organization of self-study. These are electronic courses, electronic materials, mobile devices, etc. The development of information and communication technologies has brought self-study to a new level. These tools have given great opportunities to both educational organizers and students. A large number of practitioners have used research technologies and developed their own recommendations for the use of modern technologies in the education system.

British students who study independently often look for resources on online learning platforms. Thus, in recent years, there has been an active development of measure-based software systems (distance learning platforms), the most prominent of which are: Learning Space, Top Class, WebCT (versions 3-6), Black Board, Moodle, Learn eXact, and Moodle. Black Board, Learning Space, and Learn eXact systems are very expensive; in addition, they require a high level of server requirements, for example, Learning Space requires a license for IBM Lotus Notes. The WebCT system is considerably cheaper (up to $\$ 10,000$, localization up to 1000 students). Separately stands LMS Moodle (BROAD, 2006).

Self-study in e-learning sets specific educational tasks for students. That is why the implementation of personal and individual approaches in the UK is reflected in the further development of distance education ideas - "Distance learning". Educational complexes developed and information and educational environment (INS) of the UK universities based on the approaches and principles of the organization of students' self-directed work. The aim is to change the students' attitude to the learning process and to make them responsible for the learning process and results. The principles of selection and organization of educational material, a set of methods that are used in the framework of its study, ensure a high level of motivation and cognitive activity, necessary for the organization of effective self-directed work of students, which leads to a tendency of positive change in the quality of knowledge.

For example, the University of Liverpool has about 35 online programs in various disciplines - management, information technology, and psychology. All of them are developed in cooperation with Laureate Online Education (an international network of higher education institutions). The self-study diplomas have the same value as the standard ones and are recognized throughout the world. Anglia Ruskin University is one of the largest universities in northern England. Nearly 40,000 students' study at the university. Moreover, the school boasts a high number of graduates from various nations - 85,000 from 177 countries of the world. Anglia Ruskin offers a wide range of online courses in business, technology, finance, and other subjects (PODLIESNYI, KOSTIKOV, BOROVINSKYI, 2019).

A study of the improvement of self-study in the UK based on the use of technology (SDLT) (TEO et al., 2010) showed that students' acceptance of blended learning can improve their SDL. Students' SDL processes contribute to the use of communicative Internet technologies for collaborative learning (LEE, TSAI, CHAI, KOH, 2014). The role of self-regulated learning was found to be positively related to students' perception of the learning environment and emotional outcomes (CHO, KIM, CHOI, 2017). Students who are qualified in SRL will be more likely to take the course materials (KIZILCEC, PÉREZ-SANAGUSTíN, MALDONADO, 2017).

A fascinating example of improving students' self-study at higher education institutions in Western Europe was the experience of the University of Zaragoza (Spanish University of Zaragoza). The methodology of the University of Zaragoza (Spain) is based on the method of M. Marko. According to this methodology, the students' literacy development is based on the use of interdisciplinary links with the use of Internet resources and the study of special terminology during self-study. According to the author of the methodology, the content approach to self-study of the language of professional communication lies in the use of web-quest (MARCO, 2002). When organizing self-directed work with the use of ICT, in particular, with web-quests, it is necessary to first identify the problematic task, and then to think about the expected result, and next, decide on a list of sources of information, think about the process of activity, and at the final stage - the presentation of the results of search activities. In all of this, the teacher helps, supports, guides. Therefore, WebQuest is a project-oriented didactic model that involves students' self-searching work in the Internet. They have a number of advantages, including motivation of students to learn new language 
material; organization of work in the form of purposeful research, not limited by time; activation of self-motivated individual or group activities of students, which they themselves lead.

As an example of a good use of web-quests in teaching can be an assignment of regional and cognitive nature. For example, when studying the topic "Travelling", the students are encouraged to create a detailed plan of travel to one of the cities of Spain. Students can be divided into groups of three to five people and asked to select the city they will be traveling to. At the next session, each group will present the results of their search and research activities in the form of a Power-Point presentation.

We would like to point out an effective approach to improving self-study at Jagielonski University (Krakow, Poland), which effectively implements methods to develop students' abilities and skills to perform self-monitoring of individual learning and cognitive activities. The methodology of self-monitoring combines new information teaching tools (Internet) and traditional forms of control of the results of students' educational and cognitive activities (control from the teacher's side). Thus, the author of the method T. Goban-Klas believes that in the traditional system of education self-monitoring is a means of checking the student's own skills and abilities in a certain subject or discipline, problematic moments detection, solving the differences between the used and new knowledge, practical use of newly acquired knowledge (GOBAN-KLAS, 2021).

The Polish university has developed a system of computerized tests available on the Internet, which can be used by students to independently test, and the computer to assess the level of their knowledge, skills, and abilities from certain academic disciplines. We would like to point out that the "Autotest System" program developed by Polish teachers is being implemented at the Jagiellonian University and other higher education institutions of the country. The system consists of an administrative module (methodological guidelines for using the program tests), student services module (module registration of students, the results of their test, etc.), student database (lists of students' specialty, course, and group), a database of tests, database answers. The program gives students a chance to try other solutions in case of a negative result, and the number of such attempts is not limited. The system greatly facilitates the control work of the teachers and increases the motivation of self-study and cognitive activities of Polish students.

For example, in Germany students' self-study is understood as learning that is carried out under the indirect supervision of a teacher and is called "indirect learning". In German higher education institutions, students have more time for mandatory classes. The academic workload is close to 20 academic years per day (compared to 34-36 years). In the classroom, the student learns only the basics of knowledge, and the additional material he/she has to find on their own. In this situation, the students' own cognitive activity contributes to creative self-fulfillment, the need for self-development. Nevertheless, achieving a balance between learning in the classroom and self-study is necessary, because students, as before, value the possibility of personal communication with the instructor to obtain a direct connection (VANSLAMBROUCK, ZHU, LOMBAERTS, PHILIPSEN, TONDEUR, 2018).

The Fern Universität in Hagen is the only state university that offers self-study courses in German-speaking countries and regions. The most popular commercial products for enhancing self-study are Blackboard, ANGEL, WebCT, D2L, and open-source Moodle and Sakai.

Moodle is designed to connect and communicate with students and instructors, allowing them to exchange various files in the system. In our view, the strongest side of the system and the advantage over other products, because it provides the possibility of interaction, organizing interactive learning. Every course participant can create their own profile, store data about themselves and the course in which they are taking the material, store and review the evaluations received, as well as view and save the notifications on the forum. Teachers can create their own system for evaluating students, store the results, and create tests and quizzes. Each student's time spent in the network is recorded in the system. So the instructor does not have to keep a record of students' success in the journal, he can log in Laplage em Revista (International), vol.7, n. Extra E, Aug. 2021, p.144-162 
and view the results of each student, their attendance, the quality of the tasks, and leave his comments on the success of each student, which will be available directly to that student. That is why the main advantages of introducing foreign experience, namely the Moodle software for improving self-study in domestic institutions of higher education are: interoperability, i.e. ensuring the possibility of interaction between different systems; multiple use: supports the possibility of multiple use of system components, which increases its efficiency; adaptability, which includes developing information technologies without redesigning the system and has built-in methods for providing individualized training; longevity - adheres to defined standards and allows changes without reprogramming everything; accessibility: allows the system to be operated from multiple locations (locally and remotely, from the classroom, from a workspace, or from home); software interfaces allow people of different educational level, different physical capabilities (including people with disabilities), different cultures to work; economical accessibility, as Moodle is available free of charge.

As a result, a theoretical analysis of the literature and pedagogical practice allowed us to determine that the pedagogical potential of the Moodle environment is conditioned by attributively present educational ideas in its content, which implement the philosophy of "social constructionist pedagogy" that combines the ideas of constructivism and social constructionism (D. Dewey, A. Kaye, S. Peipert, J. Piaget, E. von Glaserfeld).

These lines reflect the basic principles of humanistic pedagogy and psychology (A. Maslow, $K$. Rogers) and admit that in the center of the educational process is the student's selfdirected cognitive activity, his/her personality, abilities, and peculiarities of development (RODZHERS, 2001).

However, in the scientific literature there is not a lot of empirical data on the improvement of self-study in the learning environment. As a result, we proposed the implementation of the experience of foreign countries to improve students' self-study in the educational process of domestic institutions of higher education, namely the Moodle environment. Taking into account the previous research the students' self-study in Moodle learning environment is recognized as a subject type of educational-cognitive and practical activity of future professors, is aimed at solving a system of learning tasks, as well as tasks in the process of distributed in time interactive interaction with the developing elements of Moodle learning environment.

Improving students' self-study work (SSW) of institutions of higher education based on the educational environment Moodle - educational process, which requires a comprehensive, systemic goal-directed implementation, which is reflected in our developed model, which integrates input, structural, process-technological and output blocks structurally (Fig. 1). 
Fig. 1. The model of using the Moodle learning environment to improve students' self-study

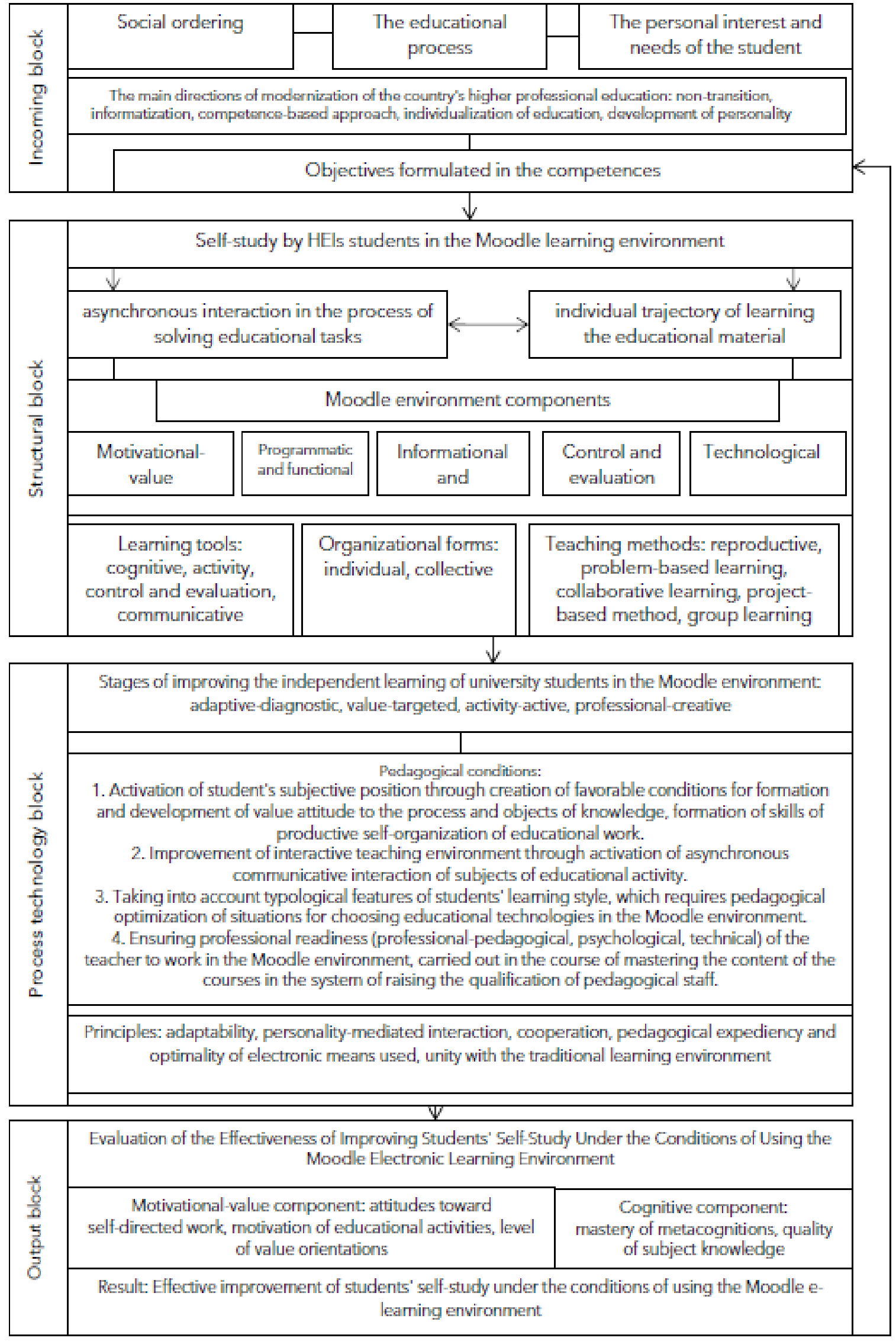

Source: Search data. 
At the same time, at the moment there is not enough material to analyze the impact of the use of electronic learning environment on self-study of students of higher education institutions of the city of Vinnitsa. Therefore, the empirical research was conducted to check the effectiveness of the proposed model for improving students' self-study in the Moodle environment, Approbation of pedagogical conditions complex on the application of Vinnitsa Commercial and Economic Institute of KNUTE (VITE KNUTE), Vinnitsa National Agrarian University and Donetsk National University named after Vasil Stus.

Stage I. According to the results of the questionnaire, 258 (or 69.2\%) out of 373 respondents do not fully use the time allotted for the self-study while 115 respondents (or $30.8 \%$ ) do fully use the time allotted for the self-study. The breakdown of respondents from VITE KNUTE, VNAU and DonNU by the amount of time used for self-study can be seen in Fig. 2.

Fig. 2 - Distribution of respondents from VITE KNUTE, VNAU and DonNU according to the amount of time spent on self-study.

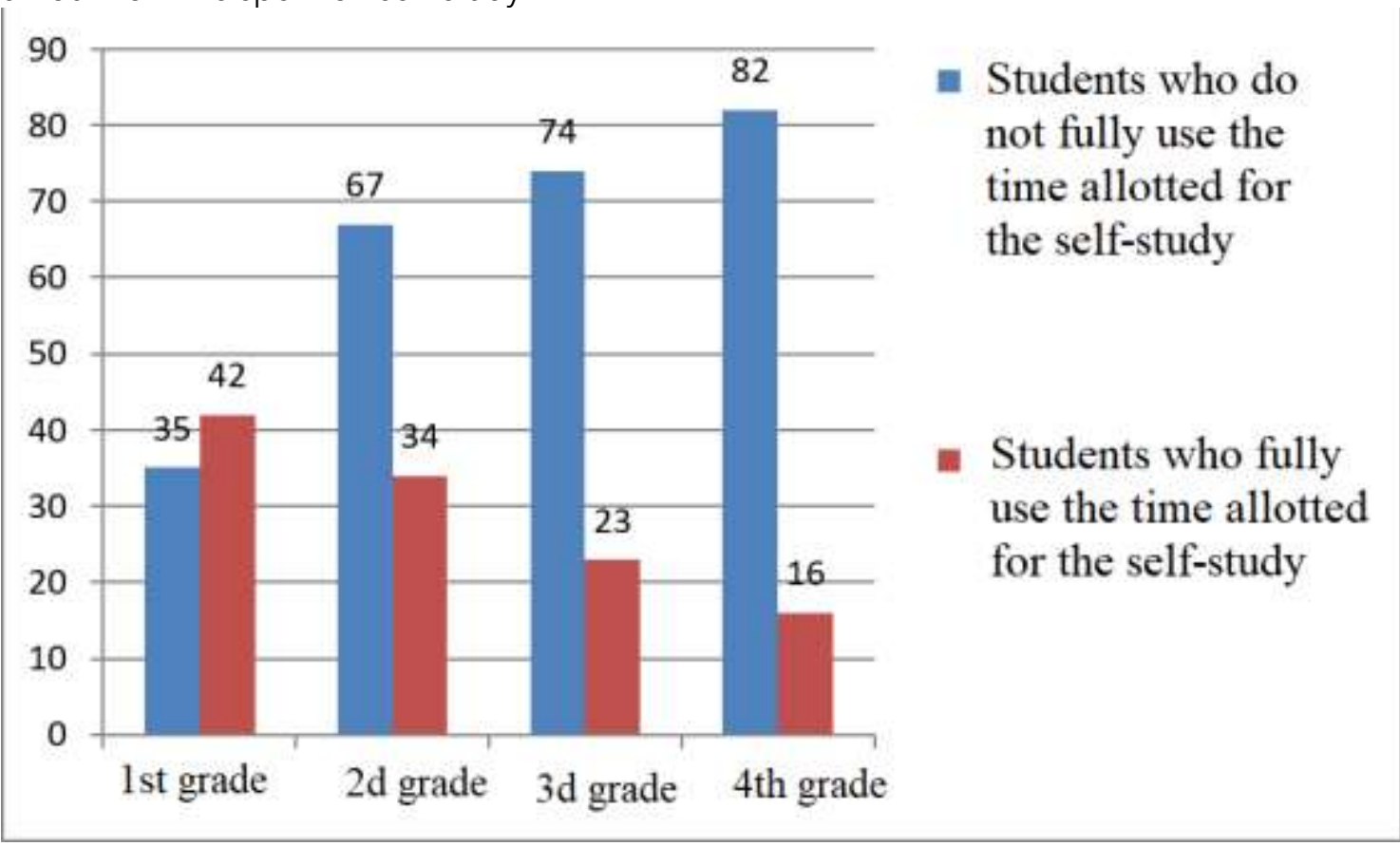

Source: Search data.

Moreover, such work is systematic only for 72 respondents or $19.3 \%$ of those studying in the 1 st-4th years, in 301 or $80.7 \%$ it is sporadic. The question about the conditions that negatively affect the results of self-study was answered with the following data: first place - lack of interest in self-study (305 respondents or $81.8 \%$ ), second - lack of individualization of selfstudy (285 respondents or $76.4 \%$ ), third - unequal nature of self-study (234 respondents or 62.7\%) (Fig. 3).

Regarding the use of distance learning technologies in the educational process and the improvement of self-study, it was found that respondents show great interest (60.8\%) and readiness to work in an electronic environment, noting its possible efficiency and productivity (54\%). At the same time, active organizational work on the systematic implementation of elearning in the educational process took place among the teachers. We found that $78 \%$ of teachers use information and communication technologies systematically, $4 \%$ do not use them at all. 
Fig. 3 - Distribution of respondents of VITE KNUTE by conditions that negatively affect the result of self-study.

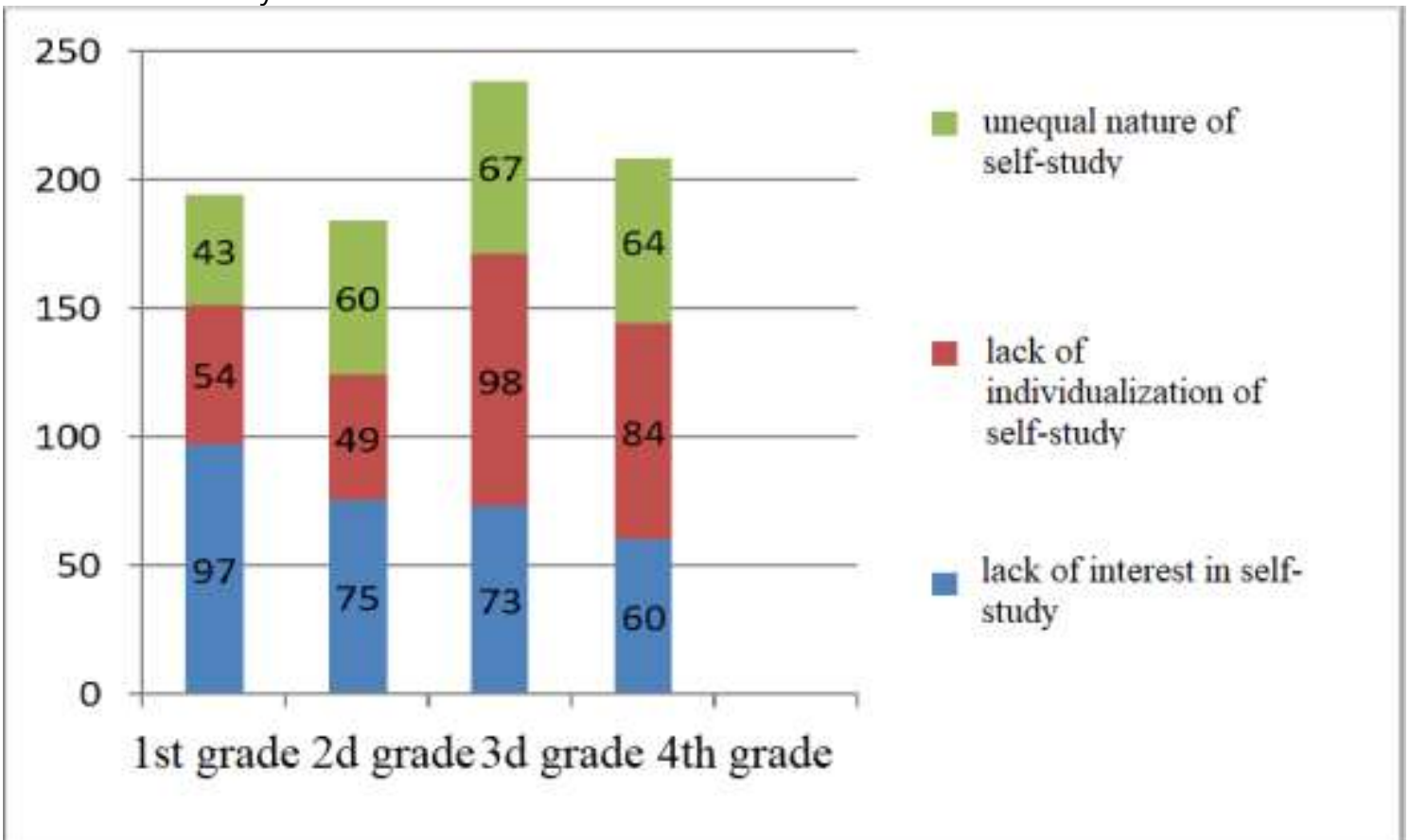

Source: Search data.

Stage II. Questionnaire, in which 35 respondents of the 1st and 2 nd years of study at VITE KNUTE, NSAU and DonNU took part: 20 PEOPLE - experimental group (EG) (mixed teaching doing self-study in Moodle learning environment) and 15 people - control group (CG) (traditional teaching - self-study without the use of information and communication technologies), allowed us to reveal the formation of the motivational component of readiness for self-study. Studying students' self-directed activity is the optimal possibility to identify the role of motivational changes in it, to understand their causal meaning, as they can well reflect the reasons that motivate them to self-directed learning.

According to F. Guay's SIMS methodology modified by T.O. Gordeeva and E.N. Osin (Gordeeva, Osin, 2011) to diagnose home learning motives, Cronbach's alpha reliability coefficient of the scale on the subscale of intrinsic cognitive motives, which characterizes interest, joy, and satisfaction in the learning process, was 0.84 ; on the subscale of intrinsic motives for achievement, which describes the feeling of personal significance and awareness of the performed self-directed activity the reliability coefficient was 0.62 ; on the subscale of external motivation (external), which describes the learning process that is spurred by the need to fulfill the duties undertaken and feelings of guilt - 0.72; on the scale of amotivation as lack of interest and sensation of awareness of self-determined activity - 0.64.

The reliability for the scales of external and internal motivational orientation - Intrinsic motivational orientations inventory by T. Amabile (Amabile, Hill, Hennessey, Tighe, 1994) was 0.84 and 0.72 respectively. To analyze the peculiarities of motivation of successful individuals as compared to unsuccessful ones, we compared two groups of students - those whose success was higher and lower than the average score of 82 for motivational changes. The results are shown in Table 1. 
Table 1 - Formation of the motivational component of students' readiness for self-study.

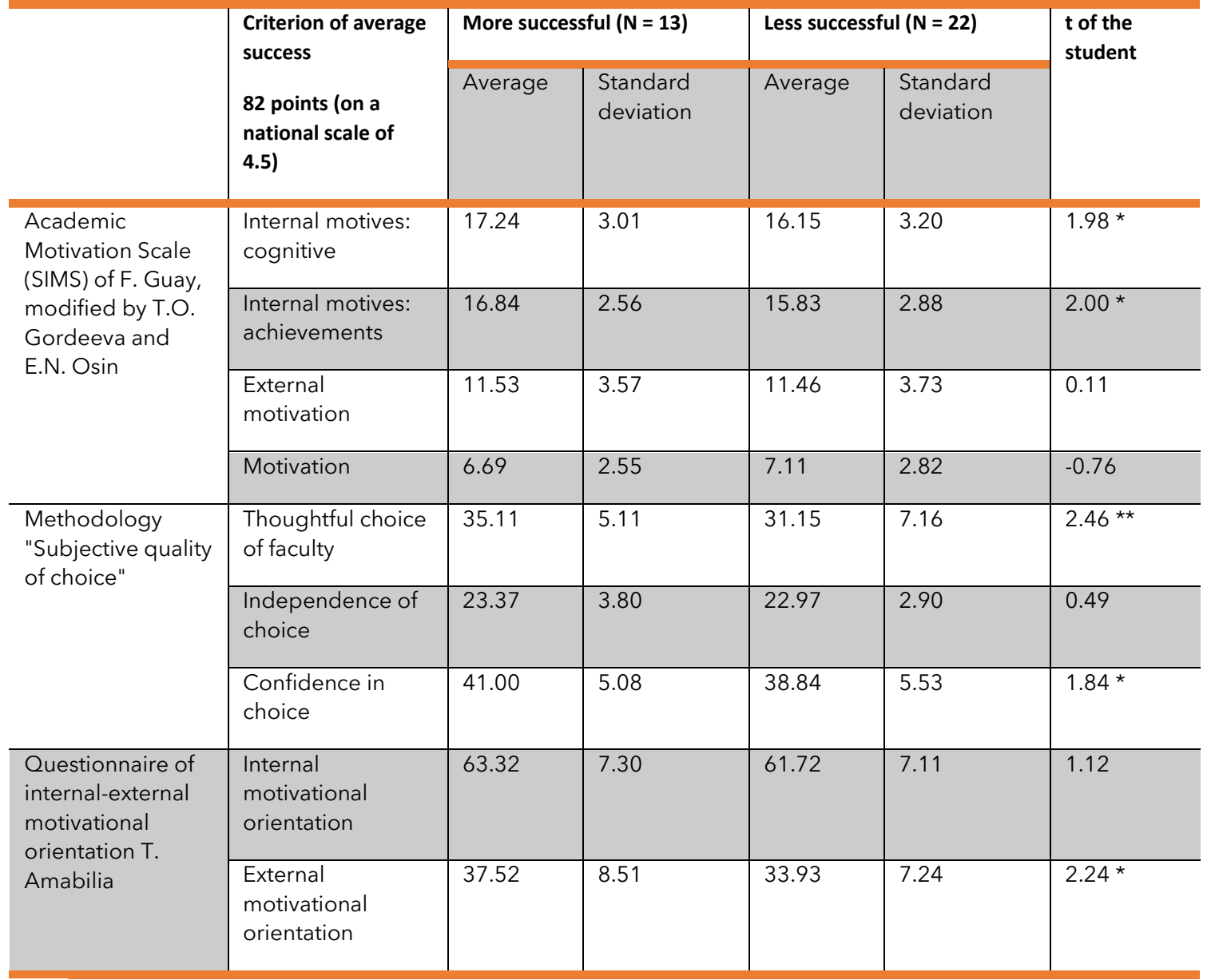

Note ${ }^{* \star *}-p<0,001 ;{ }^{* *}-p<0,01 ;{ }^{*}-p<0,05 ; p<0,1$

Source: Search data.

Thus, the students who were more successful had significantly higher cognitive learning motivation $(p<0,05)$ and, especially, learning motivation in achievement, awareness of importance of individual self-directed learning activity $(p<0,01)$.

As the data of correlation analysis show, successful students differ in indicators of learning motivation and achievement motivation, and these differences are especially important for the 1st year students. In particular, they have important motivational characteristics that ensure effective functioning of their self-study activity - intrinsic - cognitive and achievement motivation, thoughtfulness of choice of specialty (faculty). In addition, they have more external motivational orientation, which means the desire to demonstrate their achievements and capture them by the external opinion $(p<0,05)$.

The correlation analysis also shows that both internal and external motivational orientations are connected with the academic achievements $(r=0,19$ and $r=0,20$ respectively for two sessions). Stage II. This stage is experimental testing of created and provided pedagogical conditions for self-organized learning of students at VITE KNUTE, NSAU and DonNU in Moodle environment for the purpose of its improvement.

The aim of the first pedagogical condition was the activation of students' subjective position, which required the formation and development of a value attitude to the process and objects of knowledge, cognitive interest in the studied subject, skills of productive self-organization of educational work, development of activity and creative self-study in the process of selfstudy in the electronic learning environment Moodle.

The main ways of implementing this condition were modular-rating learning technology, as well as technologies of cooperative interaction (forums, glossaries, etc.), integrated use of the creativity and self-discipline in the process of self-study in the Moodle electronic learning environment), integrated use of which provided students with the possibility of self-design of 
personally meaningful content of the learning environment, the choice of options for the content of the educational material, and the distribution of an individual trajectory of its study, implementation of different types of distant subject-subject-subject interaction, increase of students' activity, and also possibility to be involved in reflexion of inter and results of individual and collective educational activity, determination of its success.

The realization of the second pedagogical condition was achieved by raising the level of communicative activity of the students in the process of solution of educational and practical tasks, order with the use of highly interactive methods (heuristic interview, presentations, discussions, brainstorming, round-table discussions, role-playing games, educational trainings, case-methods, modeling certain activities or situations, designing and writing business plans, different programs, discussing video-recordings). The main types of interactive interaction between the subjects of educational activities in the Moodle environment were identified.

The implementation of the second pedagogical condition was also carried out based on the developed algorithm of the optimal choice of means of interactive interaction of the subject of educational activity in the process of organizing independent work of students in Moodle environment and in general was as follows:

1. preliminary planning, management and control by the teacher of the process of interaction of the subject of educational activity in the Moodle environment;

2. multivariate interaction of the subject of educational activity, which allows the student in the process of independent work to choose the necessary level of subject (subjective, intersubjective) interaction to solve each specific educational task;

3. selection of at least a sufficient level of interactivity of the environment, which was determined using the Guerra scale.

To implement the third condition there were created conditions for the formation and gradual development of students' personalized learning style in the environment of Moodle. For this purpose was carried out psychological and pedagogical test of students (P. Honey and A. Mumford test), which allows to identify their existing style advantages.

The distribution was carried out on the application of the experimental group of the 2 nd year (20 students). When examining the academic success of these students we studied the examination and examination results of the 1st semester 2020-2021, as well as the number of rating points received by the students in the semester at the examinations and halls. The results of the Honey-Mumford test are summarized in the table (Table 2).

Table 2 - Distribution of VITE KNUTE students by learning styles.

\begin{tabular}{c|c|c|c|c|}
\hline \multirow{2}{*}{ Learning styles } & \multicolumn{4}{|c}{ Average number of points according to the results of the winter credit-examination session of } \\
& $90-100$ & $75-89$ & $60-74$ & $1-59$ \\
\cline { 2 - 5 } & 1 & 1 & 1 & 1 \\
\hline Theorist & 1 & 2 & 1 & 1 \\
\hline Pragmatist & 2 & - & 1 & 1 \\
\hline Activist & 4 & 2 & - & 1 \\
\hline
\end{tabular}

Source: Search data.

As can be seen from Table 1, the number of students with a high level of success is 8 people or 40\% (among them according to the learning style: 2 - activists, 4 - thinkers, 1 - theorist, 1 pragmatist). The number of students with a medium level of success is 5 persons or $25 \%$ (of them with the learning style: 2 - thinkers, 1 - theorist, 2 - pragmatists). The number of students with a low level of success is 7 persons or 35\% (of them according to the learning style: 2 activists, 1 - philosopher, 2 - theorists, 2 - pragmatists).

Students in the microgroup are selected one per row and one per student. The approach in this way allows for the formation of equal in learning capabilities microgroups, since the same microgroup, if possible, includes representatives of all learning styles and different levels of 
training. In this way, we got nine micro groups. This division is necessary for maximum adaptation of self-study in the conditions of Moodle environment to the individual peculiarities of students.

As a result, an adaptive technology for self-study of humanities disciplines as well as some thematic modules of the courses was developed. At the same time, for each type of learning style of the student in each microgroup there was an individual plan for self-study of educational materials of course modules, which considered both the sequence of study of the material, and the volume of educational elements of the module. The use of adaptive technology considering students' individual style preferences and the Moodle learning environment in improving self-study allowed students to create personal learning strategies and rationalize their learning activity as a whole.

The implementation of the fourth condition, which lies in ensuring the training of teachers to work with the Moodle system, was carried out within the framework of the courses organized at the School of Educational Mastery of VITE KNUTE under the program "Technology of developing a course for distance supervision of self-study of students". The course tested the author's methodological recommendations for teachers of higher education institutions "Education in the Moodle environment". Comprehensive approach was aimed at ensuring professional and pedagogical, psychological and technical readiness of the teachers.

Stage IV. This stage is about determining the effectiveness of the proposed model for improving the self-study of students of higher education institutions under the conditions of the Moodle learning environment. The results obtained in the course of the research were analyzed by means of mathematical and statistical data processing, as a result of which the positive dynamics for all indicators of efficiency assessment was revealed.

To verify the efficiency of the proposed model (Fig. 1), the processing of test results and questionnaire students used statistical methods of data analysis: Analysis of differences and differences in the characteristics of experimental (EG) (mixed learning) and control (CG) (traditional learning) groups on the basis of measurements carried out on the scale of correlation (Cramer-Welch criterion) and ordinal scale (Fisher criterion); calculation of the self-study satisfaction index by three components: content, organizational and psychological; analysis of differences in the characteristics of the experimental group before and after the experiment on an ordinal scale.

At the 1st level of the 4th stage the assumption of the control group's characteristics failure was confirmed (15 students, self-teaching) self-study without the use of information and communication technologies) and experimental (20 students - self-study with the use of ICT) groups before the beginning of the experiment by Cramer-Welch criterion $T e m=0.20<T 005=1.96$, i.e. the average level of ICT competence possession in the groups has no statistically reliable differences.

Comparison of the characteristics of EG before and after the experiment at 2 levels of the 4th stage determines the validity of the alternative assumption about the significance of differences at the level of $95 \%$, At that $T e l=4,60>T e, O z=1,96$, where the effect of changes is caused by the use of the experimental model of learning (educational environment Moodle).

The comparisons of EG and CG characteristics after the experiment at three levels were carried out by two criteria: Cramer-Welch $T_{\text {mesh }}=2,56>\mathrm{Te}, 05=1,96$ and Fisher's criteria $<$ rpm $=1,72><p 0,05=1,64$. The criterion $T e=2.56$ shows that the average level of IQ-competence in the groups has statistically reliable differences, and $p_{m p}=1.72$ confirms, that in $E G$ the time spent on the correct performance of the test task is less than in CG, i.e. the use of the Moodle learning environment model to improve students' self-study had a positive effect.

Also a positive effect of the developed adaptive technology of self-study of humanities disciplines (depending on the learning style) with the use of Moodle learning environment model in the 2 nd semester was the increase of academic success of students in the EG (Table 3). 
Table 3 - Distribution of VITE KNUTE students by learning styles.

\begin{tabular}{c|c|c|c|c|}
\hline \multirow{2}{*}{ Learning styles } & \multicolumn{4}{|c}{ Average number of points according to the results of the summer test-examination session of 2020- } \\
\cline { 2 - 5 } & $90-100$ & $75-89$ & $60-74$ & $1-59$ \\
\hline Theorist & 2 & 2 & - & - \\
\hline Pragmatist & 2 & 1 & - & - \\
\hline Activist & 3 & 1 & 1 & - \\
\hline Thinker & 4 & 2 & 1 & - \\
\hline
\end{tabular}

Source: Search data.

As can be seen from Table 3, the number of students with a high level of success is 11 men or $55 \%$ (among them by the learning style: 3 - activists, 4 - thinkers, 2 - theorists, 2 - pragmatists). The number of students with a medium level of success is 6 people or $30 \%$ (of them according to the learning style: 1 activist, 2 thinkers, 1 theorist, 1 pragmatist). The number of students with a low level of success is 3 persons or 15\% (of them with learning style: 1 philosopher, 2 pragmatists).

On the 4th level of the 4th stage the characteristics of the control group were compared before and after the experiment $T_{m h}=2,63>T 0,05=1,96$, These characteristics determine the validity of the alternative assumption about the significance of differences, because the CG also formed ICT competence in a traditional way, though not as effectively as the EG. At the 5th level the results of the evaluation of EG and CG students using the EOS test (Success Motivation and Fear of Failure test), modified according to the peculiarities of students' selfstudy activities, were obtained as shown in Table 4.

According to the comparative analysis of experimental data, at the stage of completion of experimental training (use of Moodle learning environment) the EG students' motivation for success in self-study increased significantly - 65\% (as compared to $25 \%$ at the beginning of the experiment), whereas the students of the control sample had a significant increase in the success motivation index: from $20 \%$ to $26.7 \%$. Motivation of fear of failure among EG students decreased from $45 \%$ to $15 \%$. The CG students had the same indicators: $46.7 \%$ and $53.3 \%$ (at the end of the experiment). Thus, we can conclude that the Moodle learning environment model suggested in the process of the research and experimental work contributes to the formation of motivational and value orientations of students for selfdirected learning activities.

Table 4 - Results of the Student Opinion Survey Using the "Success Motivation and Fear of Failure" Test (A.A. Rean).

\begin{tabular}{|c|c|c|c|c|c|c|c|c|}
\hline \multirow[t]{3}{*}{ Group } & \multirow[t]{3}{*}{$\begin{array}{l}\text { Stages of the } \\
\text { experiment }\end{array}$} & \multirow[t]{3}{*}{$\begin{array}{l}\text { Amount of } \\
\text { students }\end{array}$} & \multicolumn{2}{|c|}{$\begin{array}{l}\text { Motivation of fear of } \\
\text { failure }\end{array}$} & \multicolumn{2}{|c|}{ Motivation for success } & \multicolumn{2}{|c|}{$\begin{array}{l}\text { The motivational } \\
\text { pole is not } \\
\text { sufficiently } \\
\text { pronounced }\end{array}$} \\
\hline & & & \multicolumn{2}{|l|}{ 1-7 points } & \multicolumn{2}{|c|}{ 14-20 points } & \multicolumn{2}{|l|}{ 8-13 points } \\
\hline & & & $\begin{array}{l}\text { Number of } \\
\text { students }\end{array}$ & $\%$ & $\begin{array}{l}\text { Number of } \\
\text { students }\end{array}$ & $\%$ & $\begin{array}{l}\text { Number of } \\
\text { students }\end{array}$ & $\%$ \\
\hline EG & I stage & 20 & 9 & 45 & 5 & 25 & 6 & 30 \\
\hline EG & IV stage & 20 & 3 & 15 & 13 & 65 & 4 & 20 \\
\hline CG & I stage & 15 & 7 & 46.7 & 3 & 20 & 5 & 33.3 \\
\hline CG & IV stage & 15 & 8 & 53.3 & 4 & 26.7 & 3 & 20 \\
\hline
\end{tabular}

Source: Search data.

Also, after the experimental training (mixed) - classroom and post-exercise work (self-study of students using Moodle), the number of students with high (by 15\%) and average (by 5\%) levels and the number of students with low (by 20\%) level of academic success were observed to increase in the EG. The obtained data were processed by the method of statistical criterion Pierson "xi-square".

The value of the criterion before and after the experiment was $\chi 2$ close (10.9)> $\chi 2$ but not (5.99), with the statistical difference of $p=0.05$. The obtained differences indicate that the level of formation of academic success has increased because of the experimental work. 
Thus, the Moodle learning environment model proposed in the research-experimental work process promotes the formation of the cognitive component, i.e. the quality of the subject knowledge acquired in the conditions of self-study activities is improved.

According to the results of the 6-level evaluation, the satisfaction with the psychological side of the self-study in the Moodle environment is high and is $75 \%$, and the content side is $70 \%$, which is the average indicator. The lowest level of students' satisfaction is with the organizational aspect of self-study - 60\% (Fig. 4), which was explained by the students themselves in their responses to the open-ended questionnaire, where the conditions (Fig. 3) that have a negative impact on the result of self-study were indicated.

Fig. 4 - Results of student satisfaction with self-study in the Moodle environment.

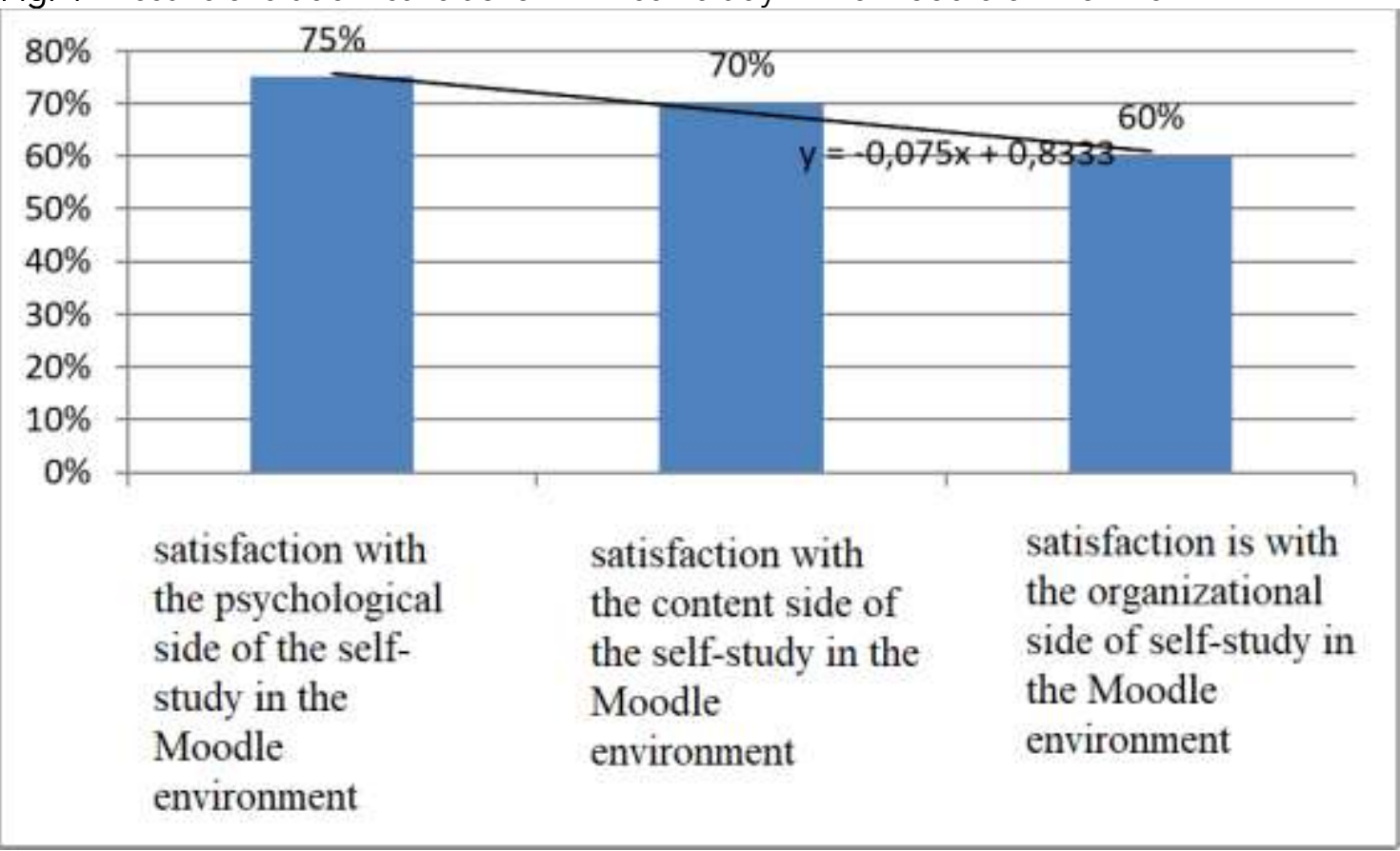

Source: Search data.

In general, the satisfaction with self-study in the Moodle environment is initially demonstrated by the linear ratio $y=-0.075 x+0.833$ and the group index, which is $69.95 \%$ and is the average level. This indicator, on the one hand, is a positive result and indicates the effectiveness of the model of Moodle learning environment for improvement of students' self-study, and, on the other hand, points to the need for management actions aimed at improving the level of organization and implementation of the educational process.

\section{DISCUSSION}

In most European universities, education is primarily designed for students' self-directed educational activities. Foreign educators note that the process of real, long-lasting and highquality acquisition and structuring of knowledge takes place only because of students' selfdirected activity. Any initiative from the revision and refinement of knowledge comes from the student himself, the task of the teacher is to provide the necessary literature and to explain complex issues in the meetings during the days allocated for this purpose. European education expects from students their personal initiative, their willingness to communicate with teachers, their readiness to create their own individual schedule of employment. At many universities, a student must first do some independent work - course work, some scientific research, etc., and submit it to the head teacher to have a lead for the scientific discussion (POON, 2013; HOCKINGS et al., 2018).

We have established that self-study is an active, goal-oriented activity of a student in acquiring, transforming, transmitting, storing, and using educational information based on realizing the capabilities of information and communication technologies.

To summarize, the most significant factors that determine peculiarities of improvement of students' self-study at VITE KNUTE, VNAU and DonNU using methods of factor and 
correlation analysis have been identified, the main peculiarities of improving students' selfstudy under the conditions of Moodle environment are manifestation of personality's subject qualities and understanding of importance of self-study in educational process of higher education institution.

Improvement of students' self-study is ensured by implementing the following pedagogical conditions: activation of student's subject position through creation of favorable conditions for formation and development of value attitude to the process and objects of knowledge, formation of skills of productive self-organization of educational work; increasing interactivity of the educational environment through activation of asynchronous communicative interaction of subjects of educational activity; taking into account typological features of students' learning styles, which requires pedagogical optimization of situations for the choice of educational technologies in the Moodle environment; ensuring professional readiness (professional-pedagogical, psychological, technical) of the teacher to work in the Moodle environment, carried out in the course of mastering the content of the courses in the system of raising the qualification of educational personnel.

\section{CONCLUSIONS}

Thus, the scientific novelty of the research lies in the following: Theoretical model of Moodle learning environment for improvement of students' self-study is developed and implemented, which includes goals, components, forms, methods, tools, results; The article provides pedagogical conditions for organizing students' self-study in VITE KNUTE, VNAU, and DonNU in Moodle environment; identifies indicators of students' proficiency level in knowledge, skills, and abilities of self-study work.

Our research has shown that the use of foreign experience in improving students' self-study, namely on the basis of the virtual learning environment Moodle, gives a number of advantages over traditional methods and forms: the possibility of implementing the principle of individuation of activity; presence of a quick connection; great opportunities for the external presentation of the material; the varied nature of self-study; activity, self-sufficiency. This learning environment allows the organization of active knowledgeable self-study activities of students, to optimize their work, increase the amount of information provided in the classroom, increase interest in learning. All this helps to obtain higher results of academic success of students in comparison with the traditional university system of training.

Practical use of the study lies in the fact that the theoretical positions, conclusions and recommendations contained in it create real conditions for improvement of students' selfstudy at domestic institutions of higher education. Developed author's methodological recommendations for teachers "Education in the Moodle environment" can be successfully used in improving the self-study of students, in the development of educational programs, tutorials.

\section{REFERENCES}

AMABILE, T.M.; HILL, K.G.; HENNESSEY, B.A.; TIGHE, E.M. The Work Preference Inventory: Assessing Intrinsic and Extrinsic Motivational Orientations. Journal of Personality and Social Psychology, 1994, 66 (5), p. 950-967.

ANDRYENKO, E. V. Values of education in different countries: traditions and innovations as factors of development. Bulletin of pedagogical innovations, 2018, 1 (49), p. 17-22.

$B R O A D$, J. Interpretations of independent learning in further education. Journal of Further and Higher Education, 2006, 2 (30), p. 119-143.

$\mathrm{CHO}, \mathrm{M} . \mathrm{H} . ; \mathrm{KIM}_{1} \mathrm{Y}$; $\mathrm{CHOI}, \mathrm{D}$. H. The effect of self-regulated learning on college students' perceptions of community of inquiry and affective outcomes in online learning. Internet \& Higher Education, 2017, 34, p. 10-17. 
DEMIR, $O$. The investigation of e-learning readiness of students and faculty members: Hacettepe University Faculty of Education example [Master Thesis]. Ankara: Hacettepe University, 2015.

DONNELLY, R. Harmonizing technology with interaction in blended problem-based learning. Computers \& Education, 2010, 54, p. 350-359.

FREEMAN, S.; EDDY, S. L.; MCDONOUGH, M.; SMITH, M. K.; OKOROAFOR, N.; JORDT, H., et al. Active learning increases student performance in science, engineering, and mathematics. Proceedings of the National Academy of Sciences, 2014, 111(23), p. 8410-8415.

GILBERT, N.; DRISCOLL, M. Collaborative knowledge building: A case study. Educational Technology Research and Development, 2002, 50, p. 59-79.

GOBAN-KLAS, T. Self-control of postcupw in science with the use of the Internet. Available at: http://www.if.uj.edu.pl. Access: July 05, 2021.

GORDEEVA, T.O.; OSIN, E.N. Optimistic attributional style as a predictor of well-being and performance in different academic settings: A new look at the problem. The Human Pursuit of Well-Being: A Cultural Approach, 2011, p. 159-174.

HONEY, P., MUMFORD, A. Using your learning styles. Maidenhead: Honey, 1986, p. 25-87.

HOCKINGS, C.; THOMAS, L.; OTTAWAY, J.; JONES, R. Independent learning - what we do when you're not there. Teaching in Higher Education, 2018, 23, p. 145-1621.

HOLEC, H. Einleitung von Henry Holec zu Autonomy and self-direkted learning: Present Fields of Application, Strabbourg, 1998.

JOSSBERGER, H.; BRAND-GRUWEL, S.; BOSHUIZEN, H.; WIEL, M. The challenge of selfdirected and self-regulatSed learning in vocational education: $A$ theoretical analysis and synthesis of requirements. Journal of Vocational Education and Training, 2010, 62 (4), p. 415440 .

KIZILCEC, R. F.; PÉREZ-SANAGUSTíN, M.; MALDONADO, J. J. Self-regulated learning strategies predict learner behavior and goal attainment in massive open online courses. Computers \& Education, 2017, 104, p. 18-33.

LEBEDEVA, K. S. Foreign experience in the study of educational and educational independence. Scientific dialogue, 2016, 2 (50), p. 374-382.

LEE, C. B.; TEO, T. Fostering self-directed learning with ICT. ICT for selfdirected and collaborative learning, 2010, p. 39-51.

LEE, K.; TSAI, P. S.; CHAl, C. S. ; KOH, J. H. L. Students' perceptions of self-directed learning and collaborative learning with and without technology. Journal of Computer Assisted Learning, 2014, 30(5), p. 425-437.

LEONTEV, D.A.; MANDRYKOVA, E.IU.; FAM, A.KH. Development of a methodology for diagnosing the procedural side of choice. Psychological diagnostics, 2007, 6, p. 4-25.

MARCO, M. J. L. Internet Content-Based Activities for English for Specific Purposes. Forum, $2002,40(3)$, p. $20-25$.

MITCHELL, A.; HONORE, S. Criteria for successful blended learning. Industrial and Commercial Training, 2007, 39 (3), p. 143-14.

MOODLE - Open-source learning platform. Available at: https://moodle.org. Access: July 08, 2021.

NEUROVA, A.B.; KAPINUS, O.S.; GRITSEVICH, T.L. Diagnosis of individual-psychological properties of personality: Educational-methodical manual. Lviv: NASV, 2016. 
OWSTON, R.; WIDEMAN, H.; MURPHY, J.; LUPSHENYUK, D. Blended teacher professional development: A synthesis of three program evaluations. The Internet and Higher Education, 2008, 11 (3-4), p. 201-210.

PETUKHOVA, T.P.; HLOTOVA, M.Y. Independent work as a means of developing information competence. Higher education in Russia, 2008, 12, p. 121-126.

PODLIESNYI, S. V.; KOSTIKOV, O. A.; BOROVINSKYI, B. V. Prospects for the use of innovative SMART-Education in ZVO. Bulletin of the Donbas State Machine-Building Academy, 2019, 1, p. $195-201$.

POON, J. Blended learning: an institutional approach for enhancing students' learning experiences. Journal of online learning and teaching, 2013, 2, p. 271-288.

REAN, A.A.; BORDOVSKAYA, N.V.; ROZUM, S.I. Psychology and pedagogy. St. Petersburg: Peter, 2002.

RODZHERS, K. R. Formation of personality. A look at psychotherapy. Moskva, 2001.

SINGH, T. Creating opportunities for students in large cohorts to reflect in and on practice: lessons learnt from a formative evaluation of students' experiences of a technology-enhaced blended learning design. British Journal of Educational Technology, 2010, 41 (2), p. 271-286.

SLOMAN, M. Making sense of blended learning. Industrial and Commercial Training, 2007, 39(6), p. 315- 318.

TEO, T.; TAN, S. C.; LEE, C. B.; CHAI, C. S.; KOH, J. H. L.; CHEN, W. L.; CHEAH, H. M. The selfdirected learning with technology scale (SDLTS) for young students: An initial development and validation. Computers \& Education, 2010, 55, p. 1764-1771.

VANSLAMBROUCK, S.; ZHU, C.; LOMBAERTS, K.; PHILIPSEN, B.; TONDEUR, J. Students' motivation and subjective task value of participating in online and blended learning environments. The Internet and Higher Education, 2018, 36, p. 33-40.

YEN, J.C.; LEE, C.Y. Exploring problem solving patterns and their impact on learning achievement in a blended learning environment. Computers \& Education, 2011, 56 (1), p. 138-145.

YILMAZ, R. Knowledge sharing behaviors in e-learning community: Exploring the role of academic self-efficacy and sense of community. Computers in Human Behavior, 2016, 63, p. 373-382. 
The educational environment for improving students' self-study: best european practices

O ambiente educacional para melhorar 0 auto-estudo dos alunos: as melhores práticas europeias

\section{El entorno educativo para mejorar el autoestudio de los estudiantes: las mejores prácticas europeas}

\section{Resumo}

O objetivo do artigo é investigar a influência do ambiente educacional no autoexame dos alunos, o que pode aprofundar a compreensão do desenho pedagógico da educação mista. Durante o estudo e avaliação de fontes informacionais foram utilizados os métodos econômicos e estatísticos, abstrato-lógicos, econômicos e matemáticos de pesquisa, métodos de análise de fatores e correlações. Os indicadores obtidos, por um lado, são resultado positivo e indicam a efetividade do modelo de utilização do ambiente educacional Moodle para melhorar o autoestudo dos alunos e, por outro, apontam para a necessidade de ações de gestão voltadas para elevar o nível de organização e implementação do processo educacional. A implementação das melhores práticas dos países europeus, ou seja, o ambiente educacional Moodle, permite a organização de atividades ativas de autoestudo cognitivo dos alunos, melhorar seu desempenho, aumentar a quantidade de informações fornecidas em sala de aula, aumentar a motivação para a aprendizagem.

Palavras-chave: Educação. Ensino superior. Personalidade. Independência. Autoeducação.

\section{Abstract}

The aim of the article is to investigate the influence of educational environment on students' self-study, which can deepen the understanding of pedagogical design of mixed education. During the study and assessment of informational sources the economical and statistical, abstract-logical, economical and mathematical research methods, methods of factor and correlation analysis were used. The obtained indicators, on the one hand, are a positive result and indicate the effectiveness of the model for the use of the educational environment Moodle to improve students' self-study, and, on the other hand, point to the need for management actions aimed at raising the level of organization and implementation of the educational process. The implementation of best practices of European countries, namely the educational environment Moodle allows the organization of active cognitive self-study activities of students, improve their performance, increase the amount of information provided in the classroom, increase motivation for learning.

Keywords: Education. Higher education. Personality. Independence. Self-education.

\section{Resumen}

El objetivo del artículo es investigar la influencia del entorno educativo en el autoestudio de los estudiantes, lo que puede profundizar en la comprensión del diseño pedagógico de la educación mixta. Durante el estudio y evaluación de las fuentes de información se utilizaron los métodos de investigación económicos y estadísticos, abstracto-lógicos, económicos y matemáticos, métodos de análisis factorial y de correlación. Los indicadores obtenidos, por un lado, son un resultado positivo e indican la efectividad del modelo para el uso del entorno educativo Moodle para mejorar el autoestudio de los estudiantes, $y$, por otro, apuntan a la necesidad de acciones de gestión dirigidas a elevar el nivel de organización e implementación del proceso educativo. La implementación de las mejores prácticas de los países europeos, es decir, el entorno educativo Moodle, permite la organización de actividades activas de autoestudio cognitivo de los estudiantes, mejorar su rendimiento, aumentar la cantidad de información proporcionada en el aula, aumentar la motivación para el aprendizaje.

Palabras-clave: Educación Enseñanza superior. Personalidad. Independencia. Autoeducación. 